\title{
Pathogenesis and radiobiology of brain arteriovenous malformations: implications for risk stratification in natural history and posttreatment course
}

\author{
Achal S. Achrol, B.S., Raphael Guzman, M.D., Monika Varga, B.S., \\ John R. Adler, M.D., Gary K. Steinberg, M.D., Ph.D., and Steven D. Chang, M.D. \\ Departments of Neurosurgery and Stanford Stroke Center Stanford University School of Medicine, Stanford, \\ California
}

Brain arteriovenous malformations (BAVMs) are an important cause of intracerebral hemorrhage (ICH) in young adults. Biological predictors of future ICH risk are lacking, and controversy exists over previous studies of natural history risk among predominantly ruptured BAVM cohorts. Recent studies have suggested that the majority of BAVMs are now diagnosed as unruptured lesions, and that the risk according to natural history among these lesions may be less than previously assumed. In the first part of this review, the authors discuss available data on the natural history of BAVMs and highlight the need for future studies that aim to develop surrogate biomarkers of disease progression that accurately predict future risk of ICH in BAVMs.

The etiology of BAVM remains unknown. Recent studies have suggested a role for genetic factors in the pathogenesis of sporadic BAVM, which is further supported by reports of familial occurrence of BAVM and association with known systemic genetic disorders (such as Osler-Weber-Rendu disease, Sturge-Weber disease, and WyburnMason syndrome). Molecular characterization of BAVM tissue demonstrates a highly angiogenic milieu with evidence of increased endothelial cell turnover. Taken together with a number of reports of de novo BAVM formation, radiographic growth after initial BAVM diagnosis, and regrowth after successful treatment of BAVM, these findings challenge the long-held assumption that BAVMs are static lesions of congenital origin. In the second part of this review, the authors discuss available data on the origins of BAVM and offer insights into future investigations into genetics and endothelial progenitor cell involvement in the pathogenesis of BAVM.

Current treatment options for BAVM focus on removal or obliteration of the lesion in an attempt to protect against future ICH risk, including microsurgical resection, endovascular embolization, and stereotactic radiosurgery (SRS). In the third part of this review, the authors discuss available data on SRS in BAVMs and highlight the need for future studies on the radiobiology of BAVMs, especially in regard to biomarker detection for tracking SRS response during the latency period.

Insights from future investigations in BAVM may not only prove important for the development of novel therapies and relevant biomarkers for BAVM, but could also potentially benefit a variety of other disorders involving new vessel formation in the CNS, including stroke, tumors, moyamoya disease, and other cerebrovascular malformations. (DOI: 10.3171/2009.2.FOCUSO926)

\section{KEY WORDS • arteriovenous malformation • angiogenesis radiosurgery $\bullet$ stroke $\bullet$ pathogenesis $\bullet$ genetics}

$\mathrm{P}$ ATIENTS harboring BAVMs are at life-threatening risk of suffering ICH. ${ }^{9,21,27,31,32,51,63,72,98}$ Despite being an uncommon disease, ${ }^{88}$ BAVMs account for the majority of childhood hemorrhagic strokes ${ }^{67}$ and represent the most common cause of isolated, nontraumatic ICH in young adults. ${ }^{79,93,96}$

In this review, we discuss current concepts and prog-

\footnotetext{
Abbreviations used in this paper: ALK1 = activin receptor-like kinase 1; ARUBA = A Randomized Trial of Unruptured BAVMs; $\mathrm{AVM}=$ arteriovenous malformation; $\mathrm{BAVM}=$ brain $\mathrm{AVM}$; EPC = endothelial progenitor cell; GWAS = genome-wide association studies; HHT = hereditary hemorrhagic telangiectasia; ICH = intracerebral hemorrhage; IL = interleukin; SDF-1 = stromal-derived factor-1; SNP = single-nucleotide polymorphism; SRS = stereotactic radiosurgery; VEGF = vascular endothelial growth factor.
}

ress in the literature regarding BAVM epidemiology, clinical management, and pathogenesis. In particular, we highlight areas of ongoing molecular and genetic research with the potential to address key issues within these areas. Insights from these investigations may not only prove important for the development of novel therapies and biomarkers specific to BAVMs, but they could also potentially benefit a wide variety of other disorders involving new vessel formation in the CNS, including stroke, tumors, moyamoya disease, and other cerebrovascular malformations.

\section{Clinical Characteristics and Natural History: A Need for Biofeedback}

Brain AVMs can present with ICH or they can be 
unruptured, that is, with symptoms resulting from mass effect, inflammation, altered hemodynamics from direct shunting, or recruitment of dilated perinidal capillary networks (for example, progressive neurological deficits, seizures, recurrent headaches, and congestive heart failure in neonates)..$^{9,21,27,31,32,51,63,72,80,98}$

Following the advent of noninvasive imaging techniques, including the widespread availability of CT and MR imaging, there has been a significant increase in the incidental detection of unruptured BAVMs ${ }^{10}$ which until now represented only a minority of BAVM diagnoses in previous studies. ${ }^{21,72}$ In most recent studies, however, unruptured BAVMs now account for the majority of cases. ${ }^{51,89}$

Some investigators have expressed concerns over the optimal management strategies for the growing number of patients harboring unruptured lesions, ${ }^{90}$ and the role of prophylactic intervention in unruptured BAVMs is the subject of ARUBA. ${ }^{6}$ These investigators pointed to the classic study of Ondra et al. ${ }^{72}$ as an example of insufficient evidence to support treatment of unruptured BAVMs. ${ }^{90}$ This study reported annual hemorrhage rates of $2-4 \%$ in patients with untreated BAVMs (major morbidity $1.7 \%$, mortality $1 \%$, and combined morbidity and mortality $2.7 \%$ per year); however, the vast majority $(71 \%)$ of these BAVMs had ruptured at initial presentation. As such, some investigators argue that these data actually blend estimates of recurrent hemorrhage risk from a majority of ruptured BAVMs with estimates of new ICH risk from a minority of unruptured BAVMs. These investigators hypothesized that, as a result, classic data likely overestimate new ICH risk among unruptured BAVMs and underestimate recurrent stroke risk among ruptured BAVMs. Similar issues have been raised regarding the classic analysis by Crawford et al. ${ }^{21}$ of 343 patients with BAVMs treated without surgery; they were found to have experienced a $42 \%$ risk of hemorrhage, a $29 \%$ risk of death, and a $27 \%$ risk of neurological morbidity by 20 years after diagnosis, as the majority of this cohort (64\%) had ruptured BAVMs at initial presentation.

Nevertheless, data are lacking to support the hypothesis that differences exist between classic AVM cohorts and modern-day cohorts in terms of overall annual ICH risk estimates or that increasing numbers of unruptured BAVMs are implicated in changing trends across studies over time. Two large, modern North American cohorts ${ }^{51,89}$ encompassing 2086 patients with BAVMs and reflecting a preponderance of unruptured lesions (53-55\%) have independently estimated the annual $\mathrm{ICH}$ risk to be $2.1-$ $2.8 \%$ overall $(1.3-1.4 \%$ for unruptured lesions, $3.7-5.9 \%$ for ruptured lesions at initial presentation). ${ }^{51,89}$ This yields overall 20-year cumulative ICH estimates of 43-56\%that is, identical to or greater than what was observed in the study by Crawford et al. ${ }^{21}$ despite a $24 \%$ decrease in the proportion of hemorrhagic presentations over time. This would seem to argue against the hypothesis that previous studies overestimated the annual risk due to a larger proportion of ruptured lesions. ${ }^{21,72}$ With a mean age of 36 years among patients with BAVM in these 2 modern studies, ${ }^{51,89}$ and assuming a life expectancy of 44 years by 2004 Social Security Actuarial Publications as previously described, ${ }^{20}$ the cumulative lifetime $\mathrm{ICH}$ risk from unruptured BAVMs in the patients in these studies is estimated to be $59 \%$, with a 5 -year stroke risk of $6.8 \%$. In one of these cohorts, $33 \%$ of patients who suffered new ICH demonstrated poor neurological outcome on 30-day modified Rankin Scale assessment (score $>2$ ), and $18 \%$ of these individuals went on to suffer recurrent hemorrhage, leaving $47 \%$ with poor neurological outcomes. ${ }^{18}$ Therefore, these data suggest that unruptured BAVMs carry a significant risk of future ICH and associated morbidity, albeit less dramatic than in ruptured BAVMs.

Given that patients with BAVMs are at lifelong cumulative risk of future ICH and typically receive the diagnosis at a young age, it is the subject of much controversy whether conclusions drawn from a 5-year study period like that of the ARUBA trial will generate accurate data of all risks and benefits comparing surgical prophylaxis against a lifetime of natural history risk from an untreated, unruptured BAVM. ${ }^{20,64}$ In the estimates above, it is clear that a 5-year cumulative stroke risk of $6.8 \%$ would appear at best to show no surgical benefit when weighed in the short term against acute surgical morbidity associated with invasive therapy. However, this would be ignoring the feared lifetime cumulative stroke risk of $59 \%$ that forms the true motivation for surgical intervention.

More recently, the AVM database of Helsinki University in Finland has provided compelling new data on the natural history of BAVM..$^{43,56}$ Reviewing $>60$ years of experience, these authors identified 631 consecutive patients with BAVMs. ${ }^{43}$ The majority of these patients, however, were excluded from the natural history analysis, which was limited to patients with at least 1 month of hemorrhage- and treatment-free follow-up. ${ }^{43}$ Nevertheless, the resulting group of 238 patients followed up for a mean duration of 13.5 years provides important data on rupture rate of untreated AVMs, even though the majority of these lesions were previously ruptured (58.4\%). ${ }^{43}$ These authors confirmed that the annual hemorrhage risk from an AVM was $2.4 \%$, noting that the rate was highest during the first 5 years after diagnosis $(4.7 \%)$ compared with $>5$ years after diagnosis (1.6\%). ${ }^{43}$ This effect was largely driven by the majority of previously ruptured lesions in this cohort, which had a $6.2 \%$ annual hemorrhage risk during the first 5 years compared with $2.3 \%$ for unruptured lesions. ${ }^{43}$ Importantly, these authors have also demonstrated that excess mortality from BAVM compared with the normal population was highest if the BAVM was treated conservatively, intermediate if the BAVM was partially occluded, and lowest if the BAVM was completely occluded. ${ }^{56}$ Once the BAVM was occluded, there was no ongoing excess death after the 1 st year. ${ }^{56}$ These authors noted that these benefits were seen 5-7 years after treatment ${ }^{56}$ and, therefore, shorter-term studies such as the ARUBA study may not be adequate to show such a benefit.

For these reasons, it is unclear whether a consensus can emerge from current clinical trials and epidemiological studies alone. This is especially true in light of the complexity of BAVM covariates that can each contribute uniquely to ICH risk in a specific patient, including age, ethnicity, traditional cardiovascular risk factors (smoking, 
hypertension, hypercholesterolemia, and diabetes), AVM size, location, venous drainage, and presence of associated aneurysms. The complexity of the disease makes it unlikely that a generalized rule, such as to offer surgery or not, can be applied on the basis of a single clinical variable alone, for example, unruptured BAVM status.

On the other hand, research efforts focusing on biofeedback have the potential to uncover disease markers that overcome the limitations of population-based research in informing treatment decisions at a patient-specific level. Proteomic analyses of sera from patients with BAVM are a promising research tool to identify biological patientspecific markers of vascular remodeling and inflammation that may signal the presence of vascular instability in a patient before the onset of a hemorrhagic event. Twodimensional polyacrylamide gel electrophoresis sorts proteins by isoelectric focusing and sodium dodecyl sulfatepolyacrylamide gel electrophoresis separates proteins by molecular weight. ${ }^{4,5,25,60}$ These techniques can be coupled with mass spectrometers, including matrix-assisted laser desorption ionization time of flight mass spectrometers (MALDI-TOF-MS) and electrospray ionization tandem mass spectrometers (ESI-tandem-MS) to detect differentially expressed proteins in sera. ${ }^{4,5,25,60}$ Protein biomarkers of interest identified by these techniques can then be validated using Western blot and immunohistochemical analysis.

In addition to proteomic approaches for serum biomarker detection, gene expression profiling of peripheral blood mononuclear cells represents another promising approach to detect patient-specific biological signals of vascular instability and inflammation by profiling immune signatures and circulating EPC expression patterns. ${ }^{84,94,95}$

These proteomic and gene expression profiling techniques may provide patient-specific data on circulating immune and endothelial progenitor cell activity that can provide clinicians early insight into the inflammation and abnormal vascular remodeling characteristic of unstable BAVMs. Such research efforts, focusing on patient-specific biofeedback as a means to stratify patients, may hold the greatest potential to address current controversies over the treatment of patients with BAVMs by offering new methods of risk stratification and treatment selection that overcome conclusions generalized from populationbased studies.

\section{Pathogenesis of BAVM}

The etiology of BAVM remains unknown. Recent studies have suggested a role for genetic factors in the pathogenesis of sporadic BAVM, ${ }^{1,2,50,73-75}$ which is further supported by reports of familial occurrence of BAVM $^{97}$ and the association of BAVM with known systemic genetic disorders (such as Osler-Weber-Rendu disease, Sturge-Weber disease, and Wyburn-Mason syndrome). ${ }^{19}$ Molecular characterization of BAVM tissue demonstrates a highly angiogenic milieu with evidence of increased endothelial cell turnover and inflammatory cell-mediated vascular remodeling. ${ }^{15-17,35-40}$ Taken together with a number of reports of de novo BAVM formation, ${ }^{11,30,78,81,85,92}$ radiographic growth after initial BAVM diagnosis, ${ }^{22,23,46,54,55,65,66,68,87}$ and regrowth after successful treatment of BAVM, ${ }^{28,29,34,44,48,76}$ these findings challenge the long-held assumption that BAVMs are static lesions of congenital origin. As such, future studies are needed that explore new paradigms in BAVM pathogenesis, including the possibility that BAVMs might represent benign slowgrowing vascular tumors (not just static congenital lesions), could result from acquired somatic mutations (not just congenital/germline mutations), and may represent aberrant adult vasculogenesis (not just persistent neonatal angiogenesis).

\section{Genetic Considerations}

Genetic analyses have the potential to uncover underlying pathogenic mechanisms of BAVM that could enhance our understanding of vascular disease and identify novel targets for therapeutic intervention. Identification of genetic markers such as SNPs could improve the understanding of BAVM physiology and may be useful in the clinical treatment of patients with BAVMs.

It is likely that the growth and clinical behavior of BAVMs are under genetic influences from multiple modifying pathways that control vascular remodeling and vasculogenesis. For example, HHT is an autosomal dominant genetic disorder with a high prevalence of BAVM, representing an interesting example of genetic influences in the development of BAVM. ${ }^{6,59}$ Whereas the incidence of sporadic BAVM in the normal population is estimated to be $0.01 \%$, incidence in HHT2 is $1 \%$, and in HHT1 it is $10 \%$, highlighting the fact that genetic dysfunction in HHT represents a "hyper-risk factor" for development of BAVM. ${ }^{6,59}$ The gene involved in HHT1 codes for endoglin, an accessory protein of transforming growth factor- $\beta$ receptor complexes, whereas HHT2 involves the gene for ALK1, a transmembrane kinase. ${ }^{59}$ The highly elevated risk of BAVM development among HHT patients suggests that germline variants of genes relating to these pathways could exert influence over risk for development of sporadic BAVMs. In fact, a common polymorphism in ALK1, thought to result in alternative splicing, has been associated with sporadic BAVM susceptibility, ${ }^{74}$ suggesting that genetic variation in genes mutated in heritable BAVM syndromes may play a role in sporadic BAVMs. Furthermore, recent evidence suggests that ALK1 is associated with vascular remodeling and arterialization in response to hemodynamic changes,${ }^{81}$ and loss of function of this gene results in loss of distinct arterial and venous boundaries in mice. ${ }^{83,86}$

Consistent with increasing evidence implicating inflammation in the pathophysiology of BAVM, ${ }^{15-17,71}$ recent studies of promoter polymorphisms in inflammatory cytokine genes have included the following: 1) association of promoter polymorphisms in IL- $1 \beta$ with BAVM susceptibility; ${ }^{50}$ 2) association of a promoter polymorphism in IL-6 with clinical presentation of ICH in BAVM and correlation of IL-6 mRNA and protein levels in resected AVM tissue with genotype; ${ }^{16,75}$ and 3) association of promoter polymorphisms in tumor necrosis factor $-\alpha$ and apolipoprotein E2 with new ICH after diagnosis ${ }^{2,73}$ as well as risk of posttreatment hemorrhage. ${ }^{1}$ These results implicate inflammatory cytokines in pathological angiogenesis and AVM formation as well as risk of $\mathrm{ICH}$ in pa- 
tients harboring BAVMs and highlight the role of genetic screening in elucidating biomechanisms of disease.

Future studies involving genetic analyses in BAVM will include the use of GWAS and high-density SNP arrays. This approach was recently applied to the study of intracranial aneurysms to identify genetic variants that showed significant association with intracranial aneurysms, with odds ratios of 1.24-1.36.7 The GWAS approaches are now being applied in BAVM with the hope of uncovering underlying pathogenic mechanisms in this important disease.

\section{Endothelial Progenitor Cells and Aberrant Vasculogenesis}

Most BAVM research has focused on abnormal angiogenesis, that is, endothelial cell sprouting from existing vessels, in the underlying pathogenesis of a BAVM. ${ }^{100}$ However, adult vasculogenesis is increasingly being understood as the pathway for adult neovascularization. ${ }^{3,12,13}$ Vasculogenesis differs from angiogenesis in that new blood vessels arise from circulating bone marrow-derived EPCs rather than from sprouting of local endothelial cells. ${ }^{3}$ During tissue ischemia, vasculogenesis is initiated via increased expression of the transcription factor HIF-1, which promotes local production of SDF-1 and VEGF-A by hypoxic endothelial cells. ${ }^{12,13}$ It is hypothesized that release of SDF-1 ligand results in reversal of a marrow/periphery gradient that normally inhibits EPC migration. ${ }^{13}$ As a result, EPCs now mobilize to the periphery where they are preferentially recruited to SDF-1 expressing ischemic tissue. ${ }^{12,13,41,57,99}$

Aberrant vasculogenesis and EPC trafficking have recently been implicated in the development of other vascular abnormalities, including infantile hemangioma ${ }^{52,53}$ and moyamoya disease. ${ }^{47}$ Children with proliferating infantile hemangioma demonstrate increased levels of mobilized $\mathrm{EPCs}^{53}$ and surgical specimens of infantile hemangioma are positive for progenitor-specific markers including CD34, AC133, and VEGF. ${ }^{52}$

Consistent with aberrant vasculogenesis as a factor in the etiology of BAVM, increased expression of HIF-1, VEGF, and VEGF receptors are detected in BAVM tissue. ${ }^{35-38,40}$ Expression of matrix metelloproteinase-9 is also increased in BAVM tissue $\mathrm{e}^{15,17,39}$ and has been shown to be hypoxia responsive ${ }^{45}$ and may result in release of EPCs by cleavage of membrane-bound kit ligand in the bone marrow. ${ }^{42}$

Recently, aberrant vasculogenesis and EPC function have been implicated in another cerebrovascular disease, moyamoya disease. ${ }^{47}$ Future studies are needed to enumerate circulating endothelial progenitor cells in patients with cerebrovascular disease in vivo by using fluorescence-activated cell sorting protocols ${ }^{24}$ and to perform blood genomic analysis on these and other circulating cell populations, as previously described..$^{62,84}$ Such studies would aid in the understanding of vascular stem cell biology, validate the utility of EPCs as a marker of cerebrovascular disease progression, and shed new light on novel therapeutic strategies for the medical management of cerebrovascular disease.

\section{Stereotactic Radiosurgery and Radiobiology of BAVMs}

Current treatment options for BAVM focus on removal or obliteration of the lesion in an attempt to protect against future ICH risk. These options include microsurgical resection, endovascular embolization, and SRS. While microsurgical resection physically removes the nidus and endovascular embolization selectively occludes feeding arteries, neither treatment is mediated by the intrinsic vascular biology of the patient in its therapeutic effect. As such, SRS represents the only biological therapy for BAVM that avoids the need for invasive treatment. Obliteration is the hallmark of successful radiosurgical treatment of BAVM, and is defined by "complete absence of pathological vessels forming the AVM nidus, disappearance or normalization of veins draining the AVM, appearance of normal circulatory kinetics, and absence of visible arteriovenous shunt."61

Despite the widespread use of SRS in the management of BAVMs, the exact mechanism of radiosurgical obliteration remains poorly understood. ${ }^{58}$ Available data regarding the biology of radiation-induced vascular obliteration result from observations in BAVM tissue resected after radiosurgical treatment ${ }^{14,82}$ and in irradiated arteries in animal models. ${ }^{8,49,70,77}$

Observations from BAVM tissue ${ }^{14,82}$ have suggested that damaged endothelial cells shrink, detach from neighboring endothelial cells and basement membrane, and permit platelet infiltration with deposition of fibrin and hyaline. As these endothelial cells slough off over time, inhibition of smooth muscle cell proliferation is lost, and smooth muscle cell migration into the subintimal layer results in collagen deposition that thickens the subintima and adventitia, progressively narrowing the lumen and eventually occluding it.

Study of irradiated arteries in animal models has suggested that the radiosensitivity of BAVMs originates in endothelial cells. ${ }^{8,49,58,70,77}$ Failed mitosis of irradiated endothelial cells, damaged by direct interactions with irradiating electrons and indirect free-radical byproducts, results in eventual apoptosis ${ }^{26}$ and initiation of radiationinduced arteriopathy. As such, it is believed that the latency period of BAVM obliteration after SRS is dependent on the turnover rate of endothelial cells, which typically ranges on the order of a couple of months to a couple of years, since initiation of the arteriopathy only manifests once endothelial cells attempt mitosis. ${ }^{26,49,58}$ Currently, the major disadvantage of SRS is the latency period before a BAVM might successfully become obliterated, during which time the patient remains unprotected against risk of new ICH. ${ }^{91}$ Widespread variation in patient response to SRS treatment of BAVMs may be the result of varying degrees of endothelial cell turnover, which is known to be abnormal in BAVMs. ${ }^{38}$

Important progress has recently been made in animal models of SRS-induced arteriopathy, ${ }^{58}$ and it provides the basis for future studies in transgenic mice as to the role of genetic variation in modulating response to SRS. Future studies in patients with BAVMs will include proteomic analyses and gene expression profiling 
of peripheral blood cell populations, which may reflect indirect interactions from circulating through diseased tissue $^{84}$ as well as direct interactions in the pathophysiology of BAVM. ${ }^{15-17,33,71}$ These peripheral blood cells could provide important biofeedback as to progression toward successful BAVM obliteration following initiation of SRS treatment. Such biomarkers of BAVM response to SRS could not only guide treatment planning but could identify novel targets for adjuvant therapies designed to promote obliteration after SRS.

\section{Conclusions}

Further investigations are needed to identify the underlying etiology of BAVMs. High-throughput proteomewide approaches promise to provide better insight into global pathways involved in the pathogenesis and radiobiology of BAVM, and identify biomarkers with the potential to address current controversies in the management of unruptured BAVMs. Studies on EPC function represent a promising new area of research that may provide insights into the mechanism of new vessel formation in BAVM and other cerebrovascular diseases. The GWAS may overcome limitations of previous candidate gene investigations in BAVM and holds the potential to uncover underlying mechanisms in BAVM pathogenesis, risk of future ICH, and differential response to SRS.

Insights from future investigations studying BAVMs may not only prove important for the development of novel therapies and relevant biomarkers for BAVM but could also potentially benefit a variety of other disorders involving new vessel formation in the CNS, including stroke, tumors, moyamoya disease, and other cerebrovascular malformations.

\section{Disclaimer/Disclosure}

This work was supported in part by Russell and Elizabeth Siegelman (GKS), Bernard and Ronni Lacroute (GKS), and the William Randolph Hearst Foundation (GKS). Further support comes from the Child Health Research Program at Stanford (RG).

\section{References}

1. Achrol AS, Kim H, Pawlikowska L, Trudy Poon KY, McCulloch CE, Ko NU, et al: Association of tumor necrosis factor-alpha-238G $>$ A and apolipoprotein E2 polymorphisms with intracranial hemorrhage after brain arteriovenous malformation treatment. Neurosurgery 61:731-740, 2007

2. Achrol AS, Pawlikowska L, McCulloch CE, Poon KY, Ha C, Zaroff JG, et al: Tumor necrosis factor-alpha-238G $>$ A promoter polymorphism is associated with increased risk of new hemorrhage in the natural course of patients with brain arteriovenous malformations. Stroke 37:231-234, 2006

3. Asahara T, Murohara T, Sullivan A, Silver M, van der Zee R, $\mathrm{Li} \mathrm{T}$, et al: Isolation of putative progenitor endothelial cells for angiogenesis. Science 275:964-967, 1997

4. Bae SM, Lee CH, Cho YL, Nam KH, Kim YW, Kim CK, et al: Two-dimensional gel analysis of protein expression profile in squamous cervical cancer patients. Gynecol Oncol 99:26-35, 2005

5. Bergquist J, Palmblad $M$, Wetterhall $M$, Hakansson $P$, Markides KE: Peptide mapping of proteins in human body fluids using electrospray ionization Fourier transform ion cyclotron resonance mass spectrometry. Mass Spectrom Rev 21:2-15, 2002

6. Berman MF, Sciacca RR, Pile-Spellman J, Stapf C, Connolly
ES Jr, Mohr JP, et al: The epidemiology of brain arteriovenous malformations. Neurosurgery 47:389-397, 2000

7. Bilguvar K, Yasuno K, Niemela M, Ruigrok YM, von Und Zu Fraunberg M, van Duijn CM, et al: Susceptibility loci for intracranial aneurysm in European and Japanese populations. Nat Genet 40:1472-1477, 2008

8. Bitzer M, Topka H: Progressive cerebral occlusive disease after radiation therapy. Stroke 26:131-136, 1995

9. Brown RD Jr, Wiebers DO, Forbes G, O'Fallon WM, Piepgras DG, Marsh WR, et al: The natural history of unruptured intracranial arteriovenous malformations. J Neurosurg 68:352-357, 1988

10. Brown RD Jr, Wiebers DO, Torner JC, O'Fallon WM: Incidence and prevalence of intracranial vascular malformations in Olmsted County, Minnesota, 1965 to 1992. Neurology 46:949-952, 1996

11. Bulsara KR, Alexander MJ, Villavicencio AT, Graffagnino C: De novo cerebral arteriovenous malformation: case report. Neurosurgery 50:1137-1140, 2002

12. Ceradini DJ, Gurtner GC: Homing to hypoxia: HIF-1 as a mediator of progenitor cell recruitment to injured tissue. Trends Cardiovasc Med 15:57-63, 2005

13. Ceradini DJ, Kulkarni AR, Callaghan MJ, Tepper OM, Bastidas N, Kleinman ME, et al: Progenitor cell trafficking is regulated by hypoxic gradients through HIF-1 induction of SDF-1. Nat Med 10:858-864, 2004

14. Chang SD, Shuster DL, Steinberg GK, Levy RP, Frankel K: Stereotactic radiosurgery of arteriovenous malformations: pathologic changes in resected tissue. Clin Neuropathol 16:111-116, 1997

15. Chen Y, Fan Y, Poon KY, Achrol AS, Lawton MT, Zhu Y, et al: MMP-9 expression is associated with leukocytic but not endothelial markers in brain arteriovenous malformations. Front Biosci 11:3121-3128, 2006

16. Chen Y, Pawlikowska L, Yao JS, Shen F, Zhai W, Achrol AS, et al: Interleukin-6 involvement in brain arteriovenous malformations. Ann Neurol 59:72-80, 2006

17. Chen Y, Zhu W, Bollen AW, Lawton MT, Barbaro NM, Dowd $\mathrm{CF}$, et al: Evidence of inflammatory cell involvement in brain arteriovenous malformations. Neurosurgery 62:1340-1350, 2008

18. Choi JH, Mast H, Sciacca RR, Hartmann A, Khaw AV, Mohr JP, et al: Clinical outcome after first and recurrent hemorrhage in patients with untreated brain arteriovenous malformation. Stroke 37:1243-1247, 2006

19. Choi JH, Mohr JP: Brain arteriovenous malformations in adults. Lancet Neurol 4:299-308, 2005

20. Cockroft KM: Unruptured brain arteriovenous malformations should be treated conservatively: no. Stroke 38:3310-3311, 2007

21. Crawford PM, West CR, Chadwick DW, Shaw MD: Arteriovenous malformations of the brain: natural history in unoperated patients. J Neurol Neurosurg Psychiatry 49:1-10, 1986

22. Delitala A, Delfini R, Vagnozzi R, Esposito S: Increase in size of cerebral angiomas. Case report. J Neurosurg 57:556-558, 1982

23. Du R, Hashimoto T, Tihan T, Young WL, Perry V, Lawton MT: Growth and regression of arteriovenous malformations in a patient with hereditary hemorrhagic telangiectasia. Case report. J Neurosurg 106:470-477, 2007

24. Duda DG, Cohen KS, Scadden DT, Jain RK: A protocol for phenotypic detection and enumeration of circulating endothelial cells and circulating progenitor cells in human blood. Nat Protocols 2:805-810, 2007

25. Fu Q, Bovenkamp DE, Van Eyk JE: A rapid, economical, and reproducible method for human serum delipidation and albumin and $\mathrm{IgG}$ removal for proteomic analysis. Methods Mol Biol 357:365-371, 2007

26. Fuks Z, Persaud RS, Alfieri A, McLoughlin M, Ehleiter D, 
Schwartz JL, et al: Basic fibroblast growth factor protects endothelial cells against radiation-induced programmed cell death in vitro and in vivo. Cancer Res 54:2582-2590, 1994

27. Fullerton HJ, Achrol AS, Johnston SC, McCulloch CE, Higashida RT, Lawton MT, et al: Long-term hemorrhage risk in children versus adults with brain arteriovenous malformations. Stroke 36:2099-2104, 2005

28. Fuwa I, Wada H, Matsumoto T: [Recurrence of AVM after disappearing on postoperative angiography-report of two cases.] No Shinkei Geka 16:887-891, 1988 (Jpn)

29. Gabriel EM, Sampson JH, Wilkins RH: Recurrence of a cerebral arteriovenous malformation after surgical excision. Case report. J Neurosurg 84:879-882, 1996

30. Gonzalez LF, Bristol RE, Porter RW, Spetzler RF: De novo presentation of an arteriovenous malformation. Case report and review of the literature. J Neurosurg 102:726-729, 2005

31. Graf CJ, Perret GE, Torner JC: Bleeding from cerebral arteriovenous malformations as part of their natural history. J Neurosurg 58:331-337, 1983

32. Halim AX, Johnston SC, Singh V, McCulloch CE, Bennett JP, Achrol AS, et al: Longitudinal risk of intracranial hemorrhage in patients with arteriovenous malformation of the brain within a defined population. Stroke 35:1697-1702, 2004

33. Hao Q, Chen Y, Zhu Y, Fan Y, Palmer D, Su H, et al: Neutrophil depletion decreases VEGF-induced focal angiogenesis in the mature mouse brain. J Cereb Blood Flow Metab 27:1853-1860, 2007

34. Hashimoto N, Nozaki K: Do cerebral arteriovenous malformations recur after angiographically confirmed total extirpation? Crit Rev Neurosurg 9:141-146, 1999

35. Hashimoto T, Emala CW, Joshi S, Mesa-Tejada R, Quick CM, Feng L, et al: Abnormal pattern of Tie-2 and vascular endothelial growth factor receptor expression in human cerebral arteriovenous malformations. Neurosurgery 47:910-919, 2000

36. Hashimoto T, Lam T, Boudreau NJ, Bollen AW, Lawton MT, Young WL: Abnormal balance in the angiopoietin-tie2 system in human brain arteriovenous malformations. Circ Res 89:111-113, 2001

37. Hashimoto T, Lawton MT, Wen G, Yang GY, Chaly T Jr, Stewart CL, et al: Gene microarray analysis of human brain arteriovenous malformations. Neurosurgery 54:410-415, 2004

38. Hashimoto T, Mesa-Tejada R, Quick CM, Bollen AW, Joshi $\mathrm{S}$, Pile-Spellman J, et al: Evidence of increased endothelial cell turnover in brain arteriovenous malformations. Neurosurgery 49:124-131, 2001

39. Hashimoto T, Wen G, Lawton MT, Boudreau NJ, Bollen AW, Yang GY, et al: Abnormal expression of matrix metalloproteinases and tissue inhibitors of metalloproteinases in brain arteriovenous malformations. Stroke 34:925-931, 2003

40. Hashimoto T, Wu Y, Lawton MT, Yang GY, Barbaro NM, Young WL: Coexpression of angiogenic factors in brain arteriovenous malformations. Neurosurgery 56:1058-1065, 2005

41. Hattori K, Heissig B, Tashiro K, Honjo T, Tateno M, Shieh JH, et al: Plasma elevation of stromal cell-derived factor-1 induces mobilization of mature and immature hematopoietic progenitor and stem cells. Blood 97:3354-3360, 2001

42. Heissig B, Hattori K, Dias S, Friedrich M, Ferris B, Hackett $\mathrm{NR}$, et al: Recruitment of stem and progenitor cells from the bone marrow niche requires MMP-9 mediated release of kitligand. Cell 109:625-637, 2002

43. Hernesniemi JA, Dashti R, Juvela S, Vaart K, Niemela M, Laakso A: Natural history of brain arteriovenous malformations: a long-term follow-up study of risk of hemorrhage in 238 patients. Neurosurgery 63:823-831, 2008

44. Higuchi M, Bitoh S, Hasegawa H, Obashi J, Hiraga S: [Marked growth of arteriovenous malformation 19 years after resection: a case report.] No Shinkei Geka 19:75-78, 1991
45. Himelstein BP, Koch CJ: Studies of type IV collagenase regulation by hypoxia. Cancer Lett 124:127-133, 1998

46. Hook O, Johanson C: Intracranial arteriovenous aneurysms; a follow-up study with particular attention to their growth. AMA Arch Neurol Psychiatry 80:39-54, 1958

47. Jung KH, Chu K, Lee ST, Park HK, Kim DH, Kim JH, et al: Circulating endothelial progenitor cells as a pathogenetic marker of moyamoya disease. J Cereb Blood Flow Metab 28:1795-1803, 2008

48. Kader A, Goodrich JT, Sonstein WJ, Stein BM, Carmel PW, Michelsen WJ: Recurrent cerebral arteriovenous malformations after negative postoperative angiograms. J Neurosurg 85:14-18, 1996

49. Kamiryo T, Lopes MB, Berr SS, Lee KS, Kassell NF, Steiner L: Occlusion of the anterior cerebral artery after Gamma Knife irradiation in a rat. Acta Neurochir (Wien) 138:983990, 1996

50. Kim H, Hysi PG, Pawlikowska L, Poon A, Burchard EG, Zaroff JG, et al: Common variants in interleukin-1-beta gene are associated with intracranial hemorrhage and susceptibility to brain arteriovenous malformation. Cerebrovasc Dis 27:176-182, 2008

51. Kim H, Sidney S, McCulloch CE, Poon KY, Singh V, Johnston SC, et al: Racial/ethnic differences in longitudinal risk of intracranial hemorrhage in brain arteriovenous malformation patients. Stroke 38:2430-2437, 2007

52. Kleinman ME, Greives MR, Churgin SS, Blechman KM, Chang EI, Ceradini DJ, et al: Hypoxia-induced mediators of stem/progenitor cell trafficking are increased in children with hemangioma. Arterioscler Thromb Vasc Biol 27:26642670, 2007

53. Kleinman ME, Tepper OM, Capla JM, Bhatt KA, Ceradini DJ, Galiano RD, et al: Increased circulating AC133+ CD34+ endothelial progenitor cells in children with hemangioma. Lymphat Res Biol 1:301-307, 2003

54. Krayenbuhl HA: Angiographic contribution to the problem of enlargement of cerebral arteriovenous malformations. Acta Neurochir (Wien) 36:215-242, 1977

55. Kuwahara S, Shima T, Ishikawa S, Uozumi T, Miyazaki M: [A clinical study of intracranial AVMs with reference to their enlargement and regression-a follow-up study with angiography and CT scan (author's transl).] Neurol Med Chir (Tokyo) 19:149-161, 1979

56. Laakso A, Dashti R, Seppanen J, Juvela S, Vaart K, Niemela M, et al: Long-term excess mortality in 623 patients with brain arteriovenous malformations. Neurosurgery 63:244245,2008

57. Lataillade JJ, Clay D, Dupuy C, Rigal S, Jasmin C, Bourin P, et al: Chemokine SDF-1 enhances circulating CD34(+) cell proliferation in synergy with cytokines: possible role in progenitor survival. Blood 95:756-768, 2000

58. Lawton MT, Arnold CM, Kim YJ, Bogarin EA, Stewart CL, Wulfstat AA, et al: Radiation arteriopathy in the transgenic arteriovenous fistula model. Neurosurgery 62:1129-1138, 2008

59. Letteboer TG, Mager JJ, Snijder RJ, Koeleman BP, Lindhout D, Ploos van Amstel JK, et al: Genotype-phenotype relationship in hereditary haemorrhagic telangiectasia. J Med Genet 43:371-377, 2006

60. Liang L, Qu L, Ding Y: Protein and mRNA characterization in human colorectal carcinoma cell lines with different metastatic potentials. Cancer Invest 25:427-434, 2007

61. Lindqvist M, Steiner L, Blomgren H, Arndt J, Berggren BM: Stereotactic radiation therapy of intracranial arteriovenous malformations. Acta Radiol Suppl 369:610-613, 1986

62. Lu A, Tang Y, Ran R, Ardizzone TL, Wagner KR, Sharp FR: Brain genomics of intracerebral hemorrhage. J Cereb Blood Flow Metab 26:230-252, 2006

63. Mast H, Young WL, Koennecke HC, Sciacca RR, Osipov A, 
Pile-Spellman J, et al: Risk of spontaneous haemorrhage after diagnosis of cerebral arteriovenous malformation. Lancet 350:1065-1068, 1997

64. Mathiesen T: Arguments against the proposed randomised trial (ARUBA). Neuroradiology 50:469-471, 2008

65. McKissock W, Paterson JH: A clinical survey of intracranial angiomas with special reference to their mode of progression and surgical treatment: a report of 110 cases. Brain 79:233266,1956

66. Mendelow AD, Erfurth A, Grossart K, Macpherson P: Do cerebral arteriovenous malformations increase in size? J Neurol Neurosurg Psychiatry 50:980-987, 1987

67. Meyer-Heim AD, Boltshauser E: Spontaneous intracranial haemorrhage in children: aetiology, presentation and outcome. Brain Dev 25:416-421, 2003

68. Minakawa T, Tanaka R, Koike T, Takeuchi S, Sasaki O: Angiographic follow-up study of cerebral arteriovenous malformations with reference to their enlargement and regression. Neurosurgery 24:68-74, 1989

69. Mohr JP: A randomized trial of unruptured brain arteriovenous malformations (ARUBA). Acta Neurochir Suppl (Wien) 103:3-4, 2008

70. Munter MW, Karger CP, Reith W, Schneider HM, Peschke P, Debus J: Delayed vascular injury after single high-dose irradiation in the rat brain: histologic immunohistochemical, and angiographic studies. Radiology 212:475-482, 1999

71. Nuki Y, Matsumoto MM, Tsang E, Young WL, van Rooijen N, Kurihara C, et al: Roles of macrophages in flow-induced outward vascular remodeling. J Cereb Blood Flow Metab, epub ahead of print, 2008

72. Ondra SL, Troupp H, George ED, Schwab K: The natural history of symptomatic arteriovenous malformations of the brain: a 24-year follow-up assessment. J Neurosurg 73:387391, 1990

73. Pawlikowska L, Poon KY, Achrol AS, McCulloch CE, Ha C, Lum K, et al: Apolipoprotein E epsilon 2 is associated with new hemorrhage risk in brain arteriovenous malformations. Neurosurgery 58:838-843, 2006

74. Pawlikowska L, Tran MN, Achrol AS, Ha C, Burchard E, Choudhry S, et al: Polymorphisms in transforming growth factor-beta-related genes ALK1 and ENG are associated with sporadic brain arteriovenous malformations. Stroke 36:22782280, 2005

75. Pawlikowska L, Tran MN, Achrol AS, McCulloch CE, Ha C, Lind DL, et al: Polymorphisms in genes involved in inflammatory and angiogenic pathways and the risk of hemorrhagic presentation of brain arteriovenous malformations. Stroke 35:2294-2300, 2004

76. Pellettieri L, Svendsen P, Wikholm G, Carlsson CA: Hidden compartments in AVMs-a new concept. Acta Radiol 38:2-7, 1997

77. Qi F, Sugihara T, Yamamoto Y, Abe K: Arterial changes following single-dose irradiation. J Reconstr Microsurg 14:153-159, 1998

78. Rodriguez-Arias C, Martinez R, Rey G, Bravo G: Recurrence in a different location of a cerebral arteriovenous malformation in a child after radiosurgery. Childs Nerv Syst 16:363-365, 2000

79. Ruiz-Sandoval JL, Cantu C, Barinagarrementeria F: Intracerebral hemorrhage in young people: analysis of risk factors, location, causes, and prognosis. Stroke 30:537-541, 1999

80. Sato S, Kodama N, Sasaki T, Matsumoto M, Ishikawa T: Perinidal dilated capillary networks in cerebral arteriovenous malformations. Neurosurgery 54:163-170, 2004

81. Schmit BP, Burrows PE, Kuban K, Goumnerova L, Scott RM: Acquired cerebral arteriovenous malformation in a child with moyamoya disease. Case report. J Neurosurg 84:677-680, 1996

82. Schneider BF, Eberhard DA, Steiner LE: Histopathology of arteriovenous malformations after gamma knife radiosurgery. J Neurosurg 87:352-357, 1997

83. Seki T, Yun J, Oh SP: Arterial endothelium-specific activin receptor-like kinase 1 expression suggests its role in arterialization and vascular remodeling. Circ Res 93:682-689, 2003

84. Sharp FR, Xu H, Lit L, Walker W, Pinter J, Apperson M, et al: Genomic profiles of stroke in blood. Stroke 38:691-693, 2007

85. Song JK, Niimi Y, Kupersmith MJ, Berenstein A: Postnatal growth and development of a cerebral arteriovenous malformation on serial magnetic resonance imaging in a child with hemangiomatosis. Case report. J Neurosurg 106:384-387, 2007

86. Sorensen LK, Brooke BS, Li DY, Urness LD: Loss of distinct arterial and venous boundaries in mice lacking endoglin, a vascular-specific TGFbeta coreceptor. Dev Biol 261:235-250, 2003

87. Spetzler RF, Wilson CB: Enlargement of an arteriovenous malformation documented by angiography. Case report. J Neurosurg 43:767-769, 1975

88. Stapf C, Labovitz DL, Sciacca RR, Mast H, Mohr JP, Sacco RL: Incidence of adult brain arteriovenous malformation hemorrhage in a prospective population-based stroke survey. Cerebrovasc Dis 13:43-46, 2002

89. Stapf C, Mast H, Sciacca RR, Choi JH, Khaw AV, Connolly ES, et al: Predictors of hemorrhage in patients with untreated brain arteriovenous malformation. Neurology 66:1350-1355, 2006

90. Stapf C, Mohr JP, Choi JH, Hartmann A, Mast H: Invasive treatment of unruptured brain arteriovenous malformations is experimental therapy. Curr Opin Neurol 19:63-68, 2006

91. Starke RM, Komotar RJ, Hwang BY, Fischer LE, Otten ML, Merkow MB, et al: A comprehensive review of radiosurgery for cerebral arteriovenous malformations: outcomes, predictive factors, and grading scales. Stereotact Funct Neurosurg 86:191-199, 2008

92. Stevens J, Leach JL, Abruzzo T, Jones BV: De novo cerebral arteriovenous malformation: case report and literature review. AJNR Am J Neuroradiol 30:111-112, 2009

93. Tanaka Y, Furuse M, Iwasa H, Masuzawa T, Saito K, Sato F, et al: Lobar intracerebral hemorrhage: etiology and a long-term follow-up study of 32 patients. Stroke 17:51-57, 1986

94. Tang Y, Lu A, Aronow BJ, Sharp FR: Blood genomic responses differ after stroke, seizures, hypoglycemia, and hypoxia: blood genomic fingerprints of disease. Ann Neurol 50:699-707, 2001

95. Tang Y, Nee AC, Lu A, Ran R, Sharp FR: Blood genomic expression profile for neuronal injury. J Cereb Blood Flow Metab 23:310-319, 2003

96. Toffol GJ, Biller J, Adams HP Jr: Nontraumatic intracerebral hemorrhage in young adults. Arch Neurol 44:483-485, 1987

97. van Beijnum J, van der Worp HB, Schippers HM, van Nieuwenhuizen O, Kappelle LJ, Rinkel GJ, et al: Familial occurrence of brain arteriovenous malformations: a systematic review. J Neurol Neurosurg Psychiatry 78:1213-1217, 2007

98. Wilkins RH: Natural history of intracranial vascular malformations: a review. Neurosurgery 16:421-430, 1985

99. Yamaguchi J, Kusano KF, Masuo O, Kawamoto A, Silver M, Murasawa S, et al: Stromal cell-derived factor-1 effects on ex vivo expanded endothelial progenitor cell recruitment for ischemic neovascularization. Circulation 107:1322-1328, 2003

100. Young WL, Yang GY: Are there genetic influences on sporadic brain arteriovenous malformations? Stroke 35:2740-2745, 2004

Manuscript submitted January, 15, 2009.

Accepted February 17, 2009.

Address correspondence to: Gary K. Steinberg, M.D., Ph.D., Department of Neurosurgery, Stanford University School of Medicine, 300 Pasteur Drive, R281 Stanford, California 943055487. email: gsteinberg@stanford.edu. 